\title{
Erratum to: Biotransformation of 1,3-propanediol cyclic sulfate and its derivatives to diols by Rhodococcus sp.
}

\author{
Yu-Cai He $\cdot$ Zhi-Cheng Tao $\cdot$ Dan-Ping Zhang • \\ Zhen-Xing Yang $\cdot$ Shan Gao $\cdot$ Cui-Luan Ma
}

Published online: 8 October 2014

(C) Springer Science+Business Media Dordrecht 2014

\section{Erratum to: Biotechnol Lett DOI 10.1007/s10529-014-1670-7}

Unfortunately, Fig. 3 has been published incorrectly in the original publication, the correct figure has been provided in this erratum.

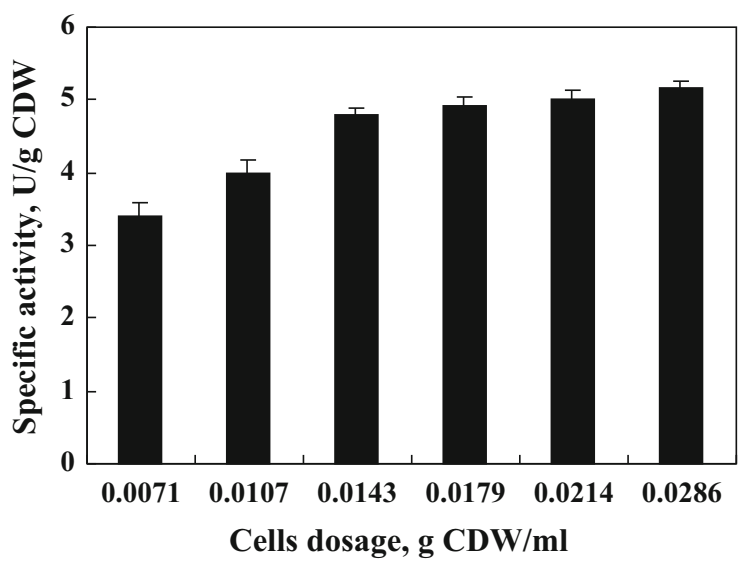

Fig. 3 Effects of cells dosage on the catalytic activity of lyophilized cells of Rhodococcus sp. CCZU10-1. Biotransformations of 1,3-PDS were performed at $30{ }^{\circ} \mathrm{C}$ and $180 \mathrm{rpm}$ in 10 $\mathrm{ml}$ potassium phosphate buffer $(100 \mathrm{mM}, \mathrm{pH} 7.5)$ containing different concentration of cells (7.1-28.6 mg CDW/ml)
The online version of the original article can be found under doi:10.1007/s10529-014-1670-7.

Y.-C. He $(\bowtie) \cdot$ Z.-C. Tao · D.-P. Zhang ·

Z.-X. Yang - S. Gao

Laboratory of Biocatalysis and Bioprocessing, College of

Pharmaceutical Engineering and Life Sciences,

Changzhou University, Changzhou 213164,

People's Republic of China

e-mail: heyucai2001@163.com

\section{C.-L. Ma $(\bowtie)$}

Changzhou Kangpu Pharmaceutical Co., Ltd.,

Changzhou 213172, People's Republic of China

e-mail: macuiluan@163.com 